\title{
Shortcut to Legitimacy: Popularity in Putin's Russia
}

Published as Derek S. Hutcheson and Bo Petersson (2016) 'Shortcut to Legitimacy: Popularity in Putin's Russia', Europe-Asia Studies 68(7) 1107-1126. There are minor textual differences between this manuscript and the final printed version. For definitive version, see:

http://dx.doi.org/10.1080/09668136.2016.1216949.

\begin{abstract}
Survey evidence suggests that Vladimir Putin’s legitimacy rests on three pillars: domestic order, economic prosperity, and the demonstration of great power status internationally. This is problematic inasmuch as it is based on high degrees of personal popularity which inhibits and contravenes the legal-rational legitimacy of state institutions. This requires continued delivery in all three areas in order to maintain the legitimacy of the regime. This framework allows us better to interpret the 2014 Ukraine crisis as an attempt to shore up support in one 'pillar' as performance-based legitimacy recedes.
\end{abstract}

Dr Derek S. Hutcheson Associate Professor of Political Science

Faculty of Culture and Society Malmö University SE-205 06 Malmö SWEDEN +46 (0)40-665 7379

derek.hutcheson@mah.se
Prof. Bo Petersson Professor of Political Science \& IMER (International Migration and Ethnic Relations) Vice Dean/Research Faculty of Culture and Society Malmö University SE-205 06 Malmö SWEDEN +46722464660 bo.petersson@mah.se 


\section{Shortcut to Legitimacy: Popularity in Putin's Russia}

\section{Derek Hutcheson \& Bo Petersson, Malmö University}

\section{Introduction}

As Vladimir Putin announced Russia’s incorporation of the Crimean Peninsula from Ukraine on 18 March 2014, his projection of personal authority and Russia's post-Soviet great power status appeared to have reached hitherto unchartered heights. Yet paradoxically, in Russia's move to a more assertive foreign policy can be seen symptoms of domestic weakness.

After the chaos of the 1990s, the first decade of the $21^{\text {st }}$ century was characterised in Russia by increased stability and the strong projection of state interests by a popular president - mirroring the centuries-old pattern of alternating 'times of troubles' and 'great power' aspirations. This article analyses the sources of this Putin-era regime stability. It argues that, in the absence of strong legal-rational legitimacy of the Weberian kind, the solidity of the current Russian regime is based primarily on the president's personal popularity, which is built on a number of 'pillars' that must be in place in order to keep the edifice stable.

Drawing our basic inspiration from the field of political sociology, we first of all define the concepts of legitimacy, popularity and the mythscape on which the Russian leadership draws. Next, we note that the Ukraine crisis in 2014 came after a period in which Vladimir Putin's previously high approval ratings had reached their lowest point in 15 years, and that the reaction to the crisis has been a marked shift in public opinion back toward the president. With the aid of survey data from 2008, 2012 and 2014, we demonstrate that Putin's popularity rests on three 'pillars': (1) the maintenance of economic growth; (2) the creation of domestic order, and (3) the skilful use of myth to project the president as the bulwark against chaos and foreign threat, in the process reinforcing Russia's status as an unequivocal 'Great Power'. To the extent that economic growth is beginning to diminish and cynicism about the

ability of the president to tackle domestic social and economic problems has increased, we conclude that Putin's recourse to the third 'pillar' - a stronger projection of Russia's interests against perceived enemies abroad - is a logical response to head off a potential regime crisis. 


\section{Defining legitimacy}

Before assessing the legitimacy of the Russian regime, we should first of all define this key concept. In a succinct definition, legitimacy is understood as a popular belief 'that a rule, institution, or leader has the right to govern' (Encyclopedia Princetoniensis 2014). Where the necessary consent between rulers and ruled is missing, social order ultimately breaks down. Most contemporary academic discussions take their point of departure in the Weberian ideal types of legal-rational, traditional and charismatic legitimacy (Weber 2006, pp. 157-8). Of these, it is the first one, founded in the meticulous adherence to constitutional rules and resting on a mandate of wide popular consent, which spells out the mature and sustainable legitimacy of contemporary democracies.

It has often been debated whether or not the concept can meaningfully be applied outside a democratic context (Peter 2014). With due regard to the dangers of conceptual stretching (Pakulski 1986), many scholars have adapted the theorising of legitimacy to make it applicable beyond the democratic nation-state (Alagappa 1995; Schlumberger and Bank 2001; Heberer and Schubert 2008), as well as to international relations (Hurd 2008) and international organisations (Beetham and Lord 1998).

In his adaptation of the Weberian apparatus to the Soviet political system, T. H. Rigby (1982) coined the concept of goal-rational legitimacy to capture the basic logic that the end (such as the ultimate achievement of communism) justifies the means. A further effort at diversifying the Weberian triad was undertaken by Leslie Holmes (1997), who among his subtypes of legitimation included the eudaemonic type, according to which popular consent is maintained as long as a minimum level of affluence is upheld and distributed to the population. This differentiation is of considerable value for the analysis of many contemporary states, Russia included. This also ties in with the difference, recognised in somewhat more recent literature, between more diffuse and long-term legitimacy which builds on commonality of values between the rulers and the ruled (input legitimacy), and more output-based legitimacy (McDonough et al. 1986; Scharpf 1999) or performance legitimacy (Burnell 2006), which rests on the ability of the rulers to deliver the goods. The latter variant of legitimacy is presumed to be of less longevity and is believed to erode in times of economic downturn - a factor that is important in the context of contemporary Russia. 


\section{Legitimacy or popularity?}

As Sil and Chen (2004) have shown, contemporary Russia is in the paradoxical situation that President Putin personally enjoys consistently very high approval ratings, and thus appears very popular, while trust in the institutions of the state - what we could provisionally call institutional legitimacy (Chen 2003) - is consistently low.

It stands to be noted, though, that approval ratings need not necessarily translate into correctly measured 'actual' popularity. First, approval can be rendered by default, due to the perceived lack of alternatives (cf. Gel'man 2010; Fish 2001). Second, one should not automatically infer that the monthly approval ratings fully reflect the 'true and inner feelings' of the electorate. Even the Levada Center, which enjoys a solid reputation in the international academic community (Treisman 2011) and is 'Russia's most respected pollster' (Balmforth 2013) notes ‘two layers of consciousness' amongst Russians, leading to circumspection as to what they are prepared to say publicly and privately (Levinson 2015). Whilst bearing this in mind, the opinion surveys used later in this article have used identical methodologies and questions over time (starting at the turn of the century before the more recent semi-authoritarian tendencies of modern Russian politics were deeply entrenched), and the findings of the later surveys are consistent with the earlier ones. Similar observations have been made in respect of other comparable surveys of presidential popularity, in which high approval ratings are accompanied by critical answers to other questions on the extent of corruption in Russian society or even Russian politics in Chechnya (Treisman 2011).

Regardless of whether the monthly approval ratings reflect genuine belief in or simply latent acceptance of the political leadership, the consistently high level of these ratings brings in the basic distinction between long-term legitimacy and short-term popularity (McDonough et al 1986; Bratton and van de Walle 1992; Rose, Munro and Mishler 2004). The former is more systemic and firmly anchored in commonality of values between rulers and ruled, whereas the latter rests primarily with individuals and their characteristics, rather than institutional arrangements. Indeed, legitimacy and popularity may even be antithetical, as the Russian case suggests. Gel'man (2010) has argued that Putin's reliance on personal popularity is an obstacle to the development of legal-rational legitimacy of state institutions. This brings to mind Sakwa's $(2011,2012)$ characterisation of contemporary Russia as a 'dual state', where a legal-normative constitutional order is constantly operating within a para-constitutional administrative regime of quick fixes and arbitrary arrangements, held together by the personal popularity of the top executive. 
Putin managed during his first two presidential tenures to establish a firm reputation of someone who managed to deliver the goods in economic terms. Gel'man (2010), like Fish (2001) before him, argues that under such conditions, supposedly less enduring legitimacy can be offered by default, through the absence of viable alternatives. As long as the incumbent basically delivers the goods and some kind of eudaemonic output legitimacy is maintained, the foundation will be viable, but if things do not run smoothly then disillusion will spread and either produce apathy and listlessness, or ultimately serve to identify contenders where there previously were none.

\section{Political myths as vehicles of legitimation}

Alongside economic delivery, we argue that the other main basis on which Putin has constructed his support has its roots in the Russian use and acceptance of political myth. All nations, big and small, tend to have their political myths that promote their ideational unity and cohesiveness and thus keep them together (Smith 1991; Hosking and Schöpflin 1997). 'The best definition of myth is the shortest: an important story', writes Boer (2009, p.9). Political myths are narratives that are believed to be true or acted on as if they were believed to be true by a substantial group of people (Petersson 2013). At a superficial level one could recognise all myths as narratives, but as pointed out by Bottici and Challand (2013, p.4), 'not all narratives are able to acquire the status of a myth'.

So in what way is the story told by myth important? One answer is that political myth is a 'common narrative that grants significance to the political conditions and experiences of a social group' (Bottici and Challand 2013, p.92). Common for political myths is that they, on the collective level, entail 'an emotional attachment that motivates political action' (Bottici and Challand 2013, p.4). The action component is of great importance. There are therefore strong links between identity, legitimacy and political action, on the one hand, and political myth, on the other, which makes political myth a highly relevant, if also somewhat neglected, field of political analysis.

Importantly, political myths do not remain eternally uncontested and they do not exist in a vacuum. Duncan Bell (2003) has discerned the national mythscape, which is the 'temporally and spatially extended discursive realm wherein the struggle for control of peoples' memories and the formation of nationalist myths is debated, contested and subverted incessantly’ (Bell 2003, p.66). Bell is quite clear that the myths therein are constructed and shaped, often by 'deliberate manipulation and intentional action’ (Bell 2003, p.75). In the 
national mythscape the myths are under continuous pressure, being challenged and contested by other constructed myths (Bell 2003; Tranter and Donoghue 2014). As a result there are what could be labelled continual 'fitness tests' (Clunan 2014) going on amongst the electorate as well as among political and other elites. When successfully performed, these fitness tests serve to legitimise the rulers. On the other hand, if the myths do not withstand the tests, they are redefined or replaced, maybe together with the political leaders that have propounded them. Only really influential myths remain basically untouched across lengthy stretches of time.

With regard to the general supply of political myths, Russia is just like most other states. However, the combination of political mythmaking with Russia's great power aspirations and non-democratic tendencies of political development makes the Russian case especially interesting to follow. The claim to be recognised as a great power (derzhava) always and regardless of the circumstances is closely intertwined with Russian national identity (Prizel 1998). This belief in the destiny-bound great power status for Russia is what we would label the first of the two predominant political myths in contemporary Russia. According to Neumann (2008), international recognition as a great power has often been withheld from Russia on the grounds that its principles of governance have been too distanced from Western ideals. However, the domestic concern seems more than anything about order, not about good governance or democracy, the latter of which has actually often been counterpoised to order in the Russian debate (Morin \& Samaranayake 2006).

It is in the context of the attributed importance of order that one should see the second and related myth in which Putin has located his leadership: that of Russia's cyclically recurring 'Times of Troubles' (sing. smuta). The paradigmatic Time of Troubles took place between 1598 and 1613, but it was neither the first nor the last one in Russian history (Parland 2005, Solovei 2003). These periods reappear from time to time to inhibit Russia's aspirations to realise its rightful great power potential and get domestic and international recognition thereof. They are periods of protracted unrest, disorderliness, power vacuum and undue foreign intervention. When they are finally ended, according to the narrative of this myth, it is thanks to the heroic efforts of the Russian people, who have become united behind a great leader who has emerged in a timely manner to deliver his country from impending disaster. The endemic strength of the people and the boldness and wisdom of the emergent leader are both factors which serve to explain why, in the discourse of its leaders and in popular belief, Russia should rightfully be regarded as a great power. According to contemporary political discourse in Russia, the most recent smuta coincided with Boris Yeltsin's presidencies (Hedlund 2006) and 
Vladimir Putin for many years personified its ending, with his emphasis on a return to order, prosperity and greatness.

\section{Putin as the political lynchpin}

Vladimir Putin has now been the central figure in the Russian political system for more a decade-and-a-half. When taking up his office for the first time, Putin declared that 'the state has to be strong, but it has become weak' (Putin 2000), and started to act accordingly. Concepts like 'dictatorship of the law' and later, the need for 'sovereign democracy', were launched in a highly determined manner, underlining the president's ambition to strengthen order inside the Russian house, make Russia respected again, and show that the country was its own master. The conception of Russia as derzhava was used by him for both legitimizing and mobilizing purposes (Anderman et al. 2007), premised on the social construction of greatness as a country that demands respect and equality from other great powers (Neumann 2008; Clunan 2009, 2014).

Following his first two presidential terms (2000-04, 2004-08), Putin stepped aside to abide by the constitutional term limit of two consecutive presidencies, but he remained as an unusually powerful prime minister to his hand-picked successor, Dmitrii Medvedev, and returned to the presidency in 2012 when Medvedev stepped aside again for his mentor. In the March 2012 presidential election, the official results credited Putin with just under 64 per cent of the vote, allowing him - as in 2000 and 2004 - to win in the first round (Central Electoral Commission 2012).

\section{FIGURE 1 ABOUT HERE}

The Medvedev-Putin swap has been likened by Sakwa (2014, p.116) to a 'constitutional coup'. Although it did not contravene the letter of the law, the assumption that the intra-elite decision to return Putin to the top position would be unquestioningly endorsed by the electorate demonstrated contempt for voters that, combined with disillusion over apparent vote-rigging in the December 2011 State Duma election, spilled over into the largest public protests for nearly two decades over the winter of 2011-12. ${ }^{1}$ It also contributed to a sharp decline in both his and Medvedev's popularity. As figure 1 shows, until February 2014 (when the Olympic Winter Games were held in Sochi and, even more importantly, the Ukraine crisis

\footnotetext{
${ }^{1}$ For a chronology of the events of the winter of 2011-2012, see Greene (2013); Smyth et al (2013); and Smyth (2014).
} 
erupted), there was a clear indication that Putin's approval ratings - whilst still positive in net terms - were lower than at any previous point. For a president building his mandate on personal popularity and in the absence of higher levels of institutionalised trust of the system more generally, this must have been seen as worrisome.

Putin was for a long time extremely deft at building his legitimacy on three pillars: economic growth, exit from the smuta (Persson and Petersson 2014) and Russia's return to greatness. As domestic economic growth has slowed, there has been a shift in Putin's third term from the 'performance' pillar towards a stronger positioning of Putin as the bulwark of stability, leading to a further shift away from output-based toward charismatic legitimacy. These charismatic elements have been easy to pick up since they have been there from the outset in Putin's presidential rhetoric and political practice, epitomised by heroic depictions of him as an omnipresent man of action (Goscilo 2013). ${ }^{2}$ However, in his third presidency, it has become even more prominent. Already on the night of his victory in March 2012 (Medvedev and Putin 2012), he equated his opponents with provocateurs attempting to 'undermine Russia's statehood and usurp power' [emphasis added], indicating a conflation between the regime, the state and his own right to rule it a qualitatively new manner. More recently, his First Deputy Chief of Staff Vyacheslav Volodin's comments at the October 2014 Valdai Discussion Club, in which he likened an attack on the president to an attack on the country and argued that 'without Putin there is no Russia' (Sivkova 2014) also point to an increasingly personalised element to Putin's rule. When the CEO of Russian Railways, Vladimir Yakunin, in spring 2015 approvingly cited a high-ranking Russian Orthodox priest to the effect that 'God gave Putin to Russia' it was another extreme public expression of this trend (Die Welt 2015).

Meanwhile, harsh domestic politics against supposedly oppositional elements, as well as Russia’s increasingly belligerent foreign policy, seem to have been focused around heading off the threat from perceived interference. As such, in the political mythmaking, domestic order, the projection of greatness abroad and the simultaneous search for 'enemies' have been used to compensate for falling eudaemonic legitimacy from economic growth, most

\footnotetext{
${ }^{2}$ Over the years, he has variously been depicted flying an SU-29 fighter jet to Chechnya 'without even removing his tie' (ORT news, 20 March 2000), riding on horseback, shooting tigers, diving for antique vases and even - on one memorable occasion - single-handedly leading some hand-reared storks on their migration path in a hangglider. Unfortunately, the last-named proved a stunt too far: his official spokesperson was forced to deny that the recurrence of 'an old sporting injury' that led to the subsequent cancellation of several presidential engagements had been caused by the Putin's ornithological aeronautics (RIA-Novosti 2012). The birds in question later had to be returned to a bird sanctuary in Russia after they failed to find their own way southwards once Putin left them (Nezavisimaya 2012).
} 
notably due to the continuing fallout from the global financial crisis. One consistent line in Putin's political strategy has clearly been to castigate outliers, to blame many if not all present ills on them, and to build Russian togetherness on the basis of fighting these allegedly malignant forces. This is a political strategy that has been employed over the last 15 years against, in chronological order, Chechnya, domestic oligarchs, Georgia, and now Ukraine and the West/USA.

\section{The game-changer: Ukraine}

The reliance on popularity and would-be charismatic and output legitimacy over legal-rational and input legitimacy contains an inherent weakness. As long as goal-rational output legitimacy is maintained, the foundation will be viable; if the incumbent ceases to deliver the goods and his personal popularity wanes at the same time as trust in state institutions remains at a low level, the system potentially contains the seeds of its own collapse. In order to maintain legitimacy, all three pillars require ever-greater amounts of mobilisation, or compensatory efforts to make up for deficits of legitimacy in any one of them. We believe that the President's hard line against Ukraine can be understood against this background.

With the unfolding of the Ukraine crisis, the dynamic of falling support rapidly switched in spring 2014 when Russia began pursuing a more assertive foreign policy. Russia's decision to admit Crimea to the Russian Federation in March 2014, following a 'request' from the breakaway government backed by a referendum of questionable legality, led to the de facto annexation of Ukrainian territory and provoked the biggest crisis of Russian-Western relations since the Cold War. The breakdown of order in eastern Ukraine over the summer of 2014, once again connected with strong suspicions of de facto Russian interference, exacerbated this. On the day that Crimea signed its accession treaty (18 March 2014), Putin gave a lengthy speech which abandoned any pretence of partnership with the West (Putin 2014a), and set the tone for Russia's foreign policy for the foreseeable future. Constructing a deft case based on the same principles of self-determination and international law espoused by the USA and others, Putin justified Russia's intervention on the humanitarian grounds of helping threatened ethnic Russians in its near abroad (Burke-White 2014; Gedmin 2014), and argued that

Our western partners, led by the United States of America, prefer not to be guided by international law in their practical policies, but by the rule of the gun. They have come to believe in their exclusivity and exceptionalism, that they can decide the destinies of the world, that only they can ever be right (Putin 2014a). 
In relation to what Russia purported to be Western instigation of the revolution in Ukraine, he argued that:

We understand what is happening; we understand that these actions were aimed against Ukraine and Russia and against Eurasian integration... we have every reason to assume that the infamous policy of containment, led in the $18^{\text {th }}, 19^{\text {th }}$ and $20^{\text {th }}$ centuries, continues today (idem).

Putin's speech showed clear echoes of the myth that the 'time of troubles' could return. On another occasion later during the spring of 2014, he accused unspecified circles in the West presumably thinly disguised references to the USA - of striving for the eventual splitting up of Russia according to the pattern set in Yugoslavia in the 1990s (Putin 2014b). At this time Putin even implied that the endeavour to quench those plans had been one of the reasons why the annexation of the Crimea was deemed necessary (idem). This kind of proactivity and assertiveness was clearly in line with the mythical imagery of Russia’s greatness. Russia was in a position to react to the provocations by the West, and demonstrate its sovereignty and strength while doing so:

With Ukraine, our western partners have crossed the line... Russia found itself in a position it could not retreat from. If you compress the spring all the way to its limit, it will snap back hard. You must always remember this (Putin 2014a).

Despite (or perhaps because of) international condemnation, including the imposition of sanctions, the more assertive policy pursued by Russia was accompanied by an almost instant increase in Putin's (and even Medvedev’s) popularity - as figure 1 showed. But the danger for Putin is that the assertive foreign policy can only compensate for falling domestic support if it is successful and sustainable. Already by the late summer of 2014, as events in eastern Ukraine became more convoluted and uncontrollable, the number of Russians stating that they 'would support the leadership of the country in the event of an armed intervention in Ukraine' had fallen to $41 \%$ (lower than the number who answered to the contrary), compared with $74 \%$ in the immediate aftermath of the Crimean annexation. ${ }^{3}$

\section{Legitimacy, Popularity, and the Mythscape: Russian Public Attitudes to Putin's regime}

In order to examine whether this increase in popularity transfers into legitimacy for the regime, we now examine in more detail each of the three 'pillars' - economic delivery, protection of

\footnotetext{
${ }^{3}$ Survey conducted by the Levada Centre and reported in RBK, 29 August 2014. Available online: http://top.rbc.ru/politics/29/08/2014/945781.shtml.
} 
domestic order, and projections of Russia's greatness - on which Putin has based his appeal to Russians over the last decade-and-a-half. Based on this, we argue that the change of foreign policy tone during the Ukrainian crisis is a logical reaction to the falling popularity that had been faced by Putin in the three years prior to it, as the regime attempts to shore up its position by shifting from output legitimacy toward a stronger reliance on the other two pillars supplied by the mythscape. We utilise quadrennial national representative surveys since 2000 to chart the vicissitudes of Russian public opinion toward the regime, with a particular focus on institutional and performance-based measures. ${ }^{4}$

Levels of trust in political institutions may be considered a proxy for legal-rational legitimacy, as depicted in table 1 . The institution imbued with most legitimacy in the eyes of Russian voters has consistently been the Russian Orthodox Church, followed by the armed forces. The presidency has been the most trusted political institution since the turn of the century, though this had fallen somewhat by the 2012-14 period. Consistently the least trusted institutions throughout the period have been the parliament and political parties - once again confirming the low legal-rational foundations of Russian democracy.

To examine popularity, we can supplement the aggregate monthly ratings listed in figure 1 with a more performance-based set of questions that measure different aspects of Putin's success. First, in response to the question 'to what extent do you approve of the actions of Vladimir Putin?', the overwhelming majority have on all occasions since 2000 expressed satisfaction. Cumulatively, 89\% of respondents in 2004, 83\% in 2008, 72\% in 2012 and 73\% in 2014 indicated ‘approval' rather than 'disapproval' of Putin's actions as president (in 2012, as prime minister), though though there was a shift in the depth of that approval. The number 'fully' rather than 'partly' approving fell from 44\% to 25\% during his period as prime minister between 2008 and 2012, a picture that was almost identical in early 2014 after two years back in the presidency.

To what extent are these two measures - institutional trust and personal approval of the incumbent - correlated? As table 2 shows, there is less connection than might generally be assumed. In each case, the scores for the 'trust' measure for the presidency and the government are correlated positively with the approval ratings of those that personify these

\footnotetext{
${ }^{4}$ For full details of the national representative surveys, conducted in early 2000, 2004, 2008, 2012 and 2014 (between the respective State Duma elections in the preceding December and presidential elections in the following March, except for 2014), see appendix. Unless otherwise indicated, figures given in this section are from these surveys.
} 
institutions. However, the Pearson correlations range between 0.35 and 0.55 - considerably short of a linear relationship. There has consistently been a stronger correlation between trust and approval of the president than between trust in the government and approval of the prime minister (even when Putin was in that office), and in 2014 there appeared to be no significant connection between trust in the government and approval of prime minister Dmitrii Medvedev at all - suggesting that high performance-based approval ratings for Putin and, to some extent, Medvedev, have not translated to into legal-rational legitimacy of the Weberian type for the institutions themselves. This provides further indication that the regime's stability depends on its ability to remain popular - rather than the legitimacy of its institutions.

\section{TABLE 2 ABOUT HERE}

\section{Performance-related satisfaction}

A more detailed breakdown of sub-issues, shown in figure 2, shows net responses under the question 'how successfully is Vladimir Putin dealing with the following problems?'. Russians were generally more impressed by Putin's competence in 2008 than more recently. The arena in which he was still regarded as having achieved most by 2014 was in restoring Russia's international pride - emphasizing the importance and success of this part of the 'great power myth' that sustained his continued popularity and to which we return below. But even in this area, the balance of opinion had shifted somewhat since 2008. Following the economic crisis and the post-Duma election demonstrations, it was notable that in 2012 and especially 2014, more people disapproved than approved of Putin's actions in the areas of economic management and the protection of democracy.

During his first two presidencies, Putin was helped along by almost unprecedented universal price hikes in oil and gas which greatly helped to sustain Russia’s then tremendous economic recovery (Bouzarovski and Bassin 2011; Rutland 2008). Gross domestic product (GDP) increased by 66\% in real terms from 2000 to 2008 (Rosstat 2014), but the country was hit hard during the world financial crisis of 2008-10, with the same reliance on oil proving a weakness as its price fell sharply. In 2009 there was a single-year loss of $7.8 \%$ of GDP (Rosstat 2014). However, the reserves which had been built up during the boom years allowed the worst of the recession to be cushioned (Teague 2011), and the Kremlin used the crisis to turn the narrative away from internal economic mismanagement towards a discourse that blamed the problems on Western economic structures and saw opportunities for a 
modernised Russia within a newly multi-polar world order (Feklyunina and White 2011) - once again demonstrating the relevance of the mythscape.

Despite the tumultuous economic circumstances during the 'tandemocracy' of Medvedev and Putin, Russians' subjective perceptions of their economic circumstances were relatively stable, though became less optimistic over time. The proportion of those who thought that the overall state of the economy was 'bad' or 'very bad' increased from $24 \%$ to $34 \%$ between 2008 and 2012, but the figure remained the same two years later. Whereas 26\% in 2012 thought that the economy had improved in the previous 12 months, this figure was only $18 \%$ by 2014, and the majority (52\%) perceived it to have got neither better nor worse. The number of respondents who noted that their own family's situation had deteriorated in the previous twelve months actually fell slightly during the financial crisis (from 27\% in 2008 to 21\% in 2012) but increased again in 2014 back to 27\%. Overall, therefore, whilst there was no overt pessimism in people's perceptions of the economy, there were signs by 2014 that most people perceived stagnation rather than strong economic growth prospects in Putin's third presidential term. The challenge will be for the Russian leadership to ensure that this perception of stagnation does not become endemic or slide into pessimism as the effect of economic sanctions begins to bite, which they appeared to be doing by autumn 2014 (Bashkatova 2014). If economic optimism falls, this means that other pillars of the Putin system may be required to take more of the strain in future.

\section{Perceptions of threat}

As we examined above, Putin has been adept at situating himself in the mythscape as a bulwark against instability and threat. At the outset, this was a fertile ground: when he became president for the first time in 2000, 38\% of those aged below 60 reported delays in the payment of their salaries over the previous twelve months, and 35\% of pensioners reported delays in their pensions (NRB8 survey, 2000). With regard to security, there had recently been a spate of (putatively Chechen-led) terrorist attacks on Russian cities. Almost three-quarters (73\%) of respondents approved of the Russian war on Chechnya in early 2000 - on which base Putin largely built his initial rise to power (NRB8 survey 2000). By 2014, as figure 2 showed, his success in Chechnya continued to meet widespread approval, but this issue was decreasingly salient as memories of the war receded. 
The same figure shows that the perception that Putin has created 'order in the country' was still shared by a small majority in 2012 and 2014, even if that number had fallen somewhat since 2008. As noted above, more recent Putin rhetoric has focused on the perception of external threat, most notably from the USA and its allies. Recent Russian incursions into Georgia and Ukraine echo Russians’ own concerns about foreign states. In an open question, in which respondents were asked to name the five countries with which they perceived Russia to have the least friendly relations, Georgia, the USA and Ukraine were the most-cited in 2012 (named by $35 \%, 31 \%$ and $18 \%$ of respondents respectively), followed by the Baltic States (Russian Research Survey 2012, E2). By early 2014, the USA had moved into first place, being named by nearly half the respondents (44\%) as a state that had unfriendly relations with Russia. Interestingly, however, the deteriorating situation in Ukraine did not seem to have come to the public consciousness even a few days before the fall of Ukrainian President Yanukovych and the annexation of Crimea. In the early 2014 survey, Ukraine was cited as hostile by approximately the same number of respondents (17\%) as in 2012 (18\%), and a narrow majority (54\%) of those with a view labelled the country as more friendly than hostile, almost mirroring the 52\% who had responded similarly in 2012 (Russia Research Survey 2012, E25; Russian Research Survey 2014, E14m).

Echoing Putin's concerns about encirclement, there was high concern amongst the Russian public that NATO expansion to Russia's borders may be a security threat. The country's foreign policy doctrine - approved in 2013 - explicitly noted 'a negative attitude towards NATO's expansion and to the approaching of NATO military infrastructure to Russia's borders' (Ministry of Foreign Affairs 2013, Art.63). When asked the hypothetical question, 'if Ukraine were to join NATO, would it be a danger to Russian security and national interests?', exactly three-quarters of respondents thought that it would (Russian Research survey 2014, E15). Similarly, the percentage of respondents who have perceived NATO as a 'platform for expansion to the East' - a threat that is clearly implied in the rhetoric of the president and the foreign ministry - had reached its highest level in a decade by 2014, with 53\% of respondents (excluding 'don't knows') tending to this view, compared with 41\% (2004), 49\% (2008) and 45\% (2012) in previous surveys.

\section{Great Power}

Closely allied to the question of perceived threat is the extent to which Russia is capable of standing up to such a peril. As we saw in table 2, one of the strongest points of approval of 
Putin is that he has restored Russia's position in the international order. To what extent, though, does the myth of Russia as a 'great power' resonate with the average Russian voter?

Russians overwhelmingly share Putin's famous declaration that the collapse of the USSR was 'the greatest geopolitical catastrophe of the [twentieth] century' (Putin 2005). ${ }^{5}$ In 2014, three in five (60\%) respondents with a view on the matter opined that it is a great pity that the USSR no longer exists' - only slightly lower than the two-thirds (67\%) who had held the same view in 2004. At the same time, the proportion of Russians who thought the Commonwealth of Independent States (CIS) should unite into a single state (resembling a neoUSSR) fell from $41 \%$ to $25 \%$ over the same period. They were also underwhelmed about Putin's much-trumpeted idea of a 'Eurasian Economic Union': 64\% of respondents in 2014 claimed to know nothing about it, and amongst the minority that did, fewer than a third thought it necessary. Taken together, these findings indicate that there remains considerable nostalgia for Russia's lynchpin role in the former Soviet space, tempered by a pragmatic realisation that it may not be possible to recreate it.

There has been a remarkably constant approval of Putin's foreign policy. ${ }^{6}$ The overwhelming majority - 69\% in 2004, 74\% in 2008, 65\% in 2012 and 69\% in 2014 - approved of the general direction of Russian foreign policy. Unsurprisingly, this figure was higher (86\% in 2012) among those who declared themselves explicit 'supporters' of the current prime minister and government, but perhaps significantly, even $49 \%$ of those who had explicitly declared themselves ‘opponents’ supported the Kremlin’s foreign policy objectives, indicating a broad-based support for the doctrine.

Furthermore, surveys carried out during the developing Ukraine crisis have indicated that there is considerable support, at least in the short-term, for Russia's incorporation of the Crimean Republic and the city of Sevastopol as the $84^{\text {th }}$ and $85^{\text {th }}$ territories of the Russian Federation - a move which is not generally recognised by the international community. In March 2014, fully 58\% of respondents indicated that Russia had a general right to incorporate former Soviet territories on the basis that 'ethnic Russians living there may have or have

\footnotetext{
${ }^{5}$ In Russian, Putin said that the USSR's collapse was the 'крупнейшей геополитической катастрофой века' (the greatest geopolitical catastrophe of the century'), though the official translation provided by the Kremlin records this as somewhat more tepidly as 'a major geopolitical disaster'.

${ }^{6}$ We do not, of course, suggest that Russia's foreign policy is determined by Putin alone; there is a complex network of interests that determines the vectors of Russian interests. Close study has suggested, however, that in Putin's third term the 'inner circle' of foreign policy advisers has noticeably shrunk (Kaczmarski 2014, pp.3967), and it is in that collective group's interest that Putin's position as the arbiter amongst different foreign policy factions is not damaged.
} 
experienced harassment and infringement of their rights by the authorities or non-Russian ethnic majority’. By late July 2014, that figure had fallen to $43 \%$, but a further $41 \%$ felt that in the particular circumstances of Crimea it had been justified and carried out in accordance with international law (Levada-Centre 2014).

\section{Building an edifice on top of the pillars - explaining Putin's support}

We have looked at each of the three pillars of Putinism - performance-related legitimacy, the preservation of order, and the restoration of Russia's 'great power' status - and found a situation in which there is a high level of personal approval for the president, but low levels of legal-rational legitimacy in the Russian political system. To conclude, we examine the extent to which these different pillars directly contribute to Putin's levels of support - and thus whether the edifice could continue to stand if any of the three pillars should weaken or collapse.

We test for various factors that explained the bases of Putin's approval ratings in 2014, with the dependent variable measured on a four-point descending scale in response to the question 'Overall, do you approve or disapprove of the activities of Vladimir Putin as president of Russia’? (Russian Research Survey 2014, B27). We construct three separate models that correspond to each of the pillars, before combining them to establish the relative importance of each to Putin's levels of approval, with the control variables of age, education level and sex included in all models. The results are shown in table 3.

\section{TABLE 3 about here}

Of the control variables, only sex has a small but significant correlation with approval of Putin when examined alone, with women slightly more likely to approve of Putin than men. This remains significant once other explanatory factors are added.

Following the base model, the first model examines the extent to which Putin's approval levels are related to delivery and performance-related factors. We include three measures: respondents' subjective impression of the state of the economy over the past twelve months (ibid., question A2; 5-point descending scale); overall impression of how things are going in the country (ibid., question B1; 5-point descending scale ${ }^{7}$ ) and a specific question that asks 'how successfully has Vladimir Putin dealt with the issue of economic growth and prosperity?' (ibid., question B28b, 4-point descending scale). The standardised beta

\footnotetext{
${ }^{7}$ Recoded from the original ascending scale in the question
} 
coefficients in Table 3 show that all three are significant predictors of overall approval for Vladimir Putin, in the expected direction, with people's evaluations of his efforts to restore national prosperity playing the largest role, and general satisfaction with the country's affairs and general economic performance a smaller and roughly equal role.

The second model focuses on perceptions of threat and stability. We include two evaluations of Putin's performance - respondents' perceptions of how successfully he has dealt with creating order in the country, and perceptions of his success in fighting Chechen rebels (ibid., questions B28a and B28e, 4-point descending scales). Moreover, we include a further perceived danger: respondents' evaluations of whether Ukraine hypothetically joining NATO would pose a threat to Russia (ibid., question E15, 4-point descending scale). This proves insignificant in 2014 - in a survey carried out just a few days before the annexation of Crimea - but those who better evaluate Putin's success in creating stability, and (to a lesser extent) his fight against Chechen terrorism, show a higher propensity to approve of his overall performance.

Model 3 focuses on the 'pillar' of foreign policy: first, an evaluation of how successfully Putin has strengthened Russia's position in the world (ibid., question B28d, 4-point descending scale) and an overall evaluation of Russian foreign policy (ibid., question E17, 4point descending scale). Both variables prove significant predictors, with strong perceptions that Putin has restored Russia's standing in the world contributing slightly more to the evaluation.

These models show that the three pillars by themselves each have a significant relationship with overall approval levels of Vladimir Putin. The $\mathrm{R}^{2}$ statistics indicate that, alone, they each explain between a fifth and a quarter of the variance in the absence of any other factors. Combining them into a single model increases the $\mathrm{R}^{2}$ to 0.380 , with all the variables except for approval of the Chechen War (which is arguably diminishing over time as a salient issue in any case) remaining significant. As for the relative contributions of each, evaluations of Putin's success in restoring order was by 2014 the single biggest predictor of overall approval of his actions, with people's perceptions of Russian foreign policy and Russia's role in the world playing the next largest role, and economic performance also proving significant - but slightly less of a contributory factor than in 2008 and 2012, as will be discussed below.

Repeating the same model and going back to the 2008 and 2012 surveys shows that the same factors played a significant role in explaining support for Putin as president and (in 2012) prime minister, as the last two columns of table 3 demonstrate. In short, the 'three 
pillar' structure to his support is borne out by the survey responses over a significant period of time. It is worth noting, however, that the relative strength of each 'pillar' has changed somewhat, with the economic delivery factors gradually diminishing as explanatory factors though remaining important - and the perception that Putin has strengthened Russia's role in the world playing a more significant role by 2014 than in 2008. This confirms our proposition that, as the economy began to falter in 2012-14, the other two pillars had to be strengthened to compensate, and suggests that there is some justification for arguing that the 'three pillars of Putinism' together hold up the edifice of his approval rating, and that each must support each other in order to maintain the edifice. We maintain that the foreign policy events of 2014 are more readily understandable against this background.

\section{Conclusions}

The above analysis has suggested that, despite a general lack of legal-rational trust in the institutions of the Russian state, the system has nonetheless continued to function relatively effectively over the past 15 years, driven in the main by the consistently very high approval ratings of the man at the top of it. We have argued that Putin's popularity rests on three 'pillars' of economic delivery, stability in the face of threat, and the projection of Russia's great power status in foreign policy.

Survey evidence has shown that Putin's popularity has consistently rested on the continued positive evaluations of the Russian population in each of these three areas. Thus, the sag in his approval ratings that began shortly before the 2011-12 electoral cycle (and continued for the first two years of his renewed term in the Kremlin) had the potential to cause systemic disruption if left unchecked. To be sure, formal political institutions continue to afford Putin a dominant role, and genuine mass support for him continues to exist. However, the demonstrations of 2011-2012 indicated cracks in the façade (Gel'man 2013), and Russians were increasingly losing their awe of him as he resumed the presidency. In a system that is based on the central role of a single individual, whose legitimacy rests mainly on charisma and popularity and whose electoral mandate is the formalisation rather than the foundation of this legitimacy, this is an ominous sign.

It is in this context that we argue the events of 2014 in Ukraine can partly be understood as a response to domestic pressures. As performance-based legitimacy had begun to diminish, fresh impetus was required in the other two pillars in order to ensure that the slump in popularity did not reach a level that threatened regime stability. Thus, the increasingly 
assertive foreign policy presence of Russia allows Putin to demonstrate the continued 'great power' relevance of Russia after the protracted marginalisation and weakness of the 1990s. At the same time, the framing of the Ukraine crisis as a threat to Russian security from neighbouring countries and the West allows Putin to re-establish his credentials as the bulwark of stability in the face of potential instability.

So what are the long-term prospects? With no political heir apparent in sight, systemic stability would seem to contingent on Putin's continued physical and political wellbeing. The assertive foreign policy that Russia is pursuing has succeeded, for now, in stemming the fall in the president's popularity and given at least a short-term boost to the system's legitimacy of the charismatic rather than legal-rational type. But it is a risky policy, and whilst the reprobation of the West has temporarily allowed Putin to shore up his domestic role against that threat, a leadership crisis may be in the offing if the economic consequences prove more negative than expected, or a swift resolution to the Ukrainian crisis is not achieved. Moreover, the regime's continued need to shore up its popularity at home by assertive behaviour abroad gives certain reason for neighbouring states to worry and may portend a continuously tense climate of relations between Russia and the West. 


\section{References}

\section{National Representative Surveys/Acknowledgements}

The following Russian surveys are used in this paper. All surveys used nationally representative samples and are used by kind permission of the original compilers or according to normal Data Archive rules (where appropriate) and the original compilers bear no responsibility for any errors of interpretation of the survey data by the current authors. Where appropriate, the datasets have been reweighted by demographic attributes and actual election turnout by the current authors.

- NRB8: New Russia Barometer (2000): Centre for the Study of Public Policy, University of Strathclyde, New Russia Barometer VIII (2000), fieldwork conducted by VTsIOM, 13-29 January 2000, $\mathrm{N}=1,940$.

- Russian Research survey (2004): Stephen White, Margot Light and Roy Allison, Inclusion without Membership? Bringing Russia, Ukraine and Belarus closer to "Europe" dataset, funded by UK ESRC grant RES-000-23-0146, fieldwork conducted by Russian Research Ltd, 21 December 2003-16 January 2004, N=2,000.

- Russian Research Survey (2008): Derek S. Hutcheson, Stephen White and Ian McAllister, National representative survey dataset, co-funded by British Academy Small Research Grant BA-40918 (Derek Hutcheson) and UK ESRC grant RES-000-222532 (Ian McAllister and Stephen White), fieldwork conducted by Russian Research Ltd., 30 January-27 February 2008, N=2,000.

- Russian Research survey (2012): Stephen White and Ian McAllister, National representative survey dataset funded by UK ESRC grant ES/J004731/1, fieldwork conducted by Russian Research Ltd., 3-23 January 2012, N=1,600.

- Russian Research survey (2014): Stephen White, Jane Duckett, Ian McAllister and Neil Munro, National representative survey dataset funded by UK ESRC grants ES/J012688/1 and ES/J004731/1, fieldwork conducted by Russian Research Ltd., 25 January-17 February 2014, N=1,601.

\section{Other literature}

- Alagappa, M. (ed.) (1995) Political Legitimacy in Southeast Asia: The Quest for Moral Authority (Stanford UP).

- Anderman, K., Hagström Frisell, E. and Vendil Pallin, C. (2007) Russia-EU External Security Relations: Russian Policy and Perceptions (Stockholm, FOI). 
- Balmforth, T. (2013) ‘Levada Center, Russia’s Most Respected Pollster, Fears Closure’, http://www.rferl.org/content/russia-levada-center-foreignagent/24992729.html, accessed 14 July 2015.

- Bashkatova, A. (2014), 'Vzryvoopasnoe sostoyanie rossiiskoi ekonomiki', Nezavisimaya Gazeta, 3 October, p.1.

- Beetham, D. and Lord, C. (1998). Legitimacy and the EU (London: Longman).

- Bell, D. S. A. (2003) 'Mythscapes: Memory, mythology, and national identity', The British Journal of Sociology 54, 1: 63-81.

- Boer, R. (2009) Political Myth: On the Use and Abuse of Biblical Themes. Durham and London: Duke University Press.

- Bottici, C. and Challand, B. (2013) Imagining Europe: Myth, Memory, and Identity. New York: Cambridge University Press.

- Bouzarovski, S. and Bassin, M. (2011) 'Energy and identity: Imagining Russia as a Hydrocarbon Superpower', Annals of the Association of American Geographers 101, 4: 783-794.

- Bratton, M. and Van de Walle, N. (1992) 'Popular Protest and Political Reform in Africa', Comparative Politics 24, 4: 419-442.

- Burke-White, W.W. (2014) 'Crimea and the International Legal Order', Survival, 56, 4, 65-80.

- Burnell, P.J. (2006) 'Autocratic Opening to Democracy: Why Legitimacy Matters’, Third World Quarterly 27, 4: 545-62.

- Central Electoral Commission of the Russian Federation (2012), 'Vybory Prezidenta Rossiiskoi Federatsii 4 marta 2012: Protokol’, available online: http://www.cikrf.ru/banners/prezident_2012/itogi/protokol.pdf, accessed 14 July 2015.

- Chen, C. (2003) 'Institutional Legitimacy of an Authoritarian State: China in the Mirror of Eastern Europe.’ Problems of Post-Communism 52, 4: 3-13.

- Clunan, A.L. (2009) The Social Construction of Russia's Resurgence: Aspirations, Identity, and Security Interests (Baltimore, Johns Hopkins University Press).

- Clunan, A. L. (2014). Historical aspirations and the domestic politics of Russia's pursuit of international status. Communist and Post-Communist Studies 47, 3-4: 28190. 
- Die Welt (2015), '"Erwarten Sie, dass wir uns isolieren lassen?"', http://www.welt.de/wirtschaft/article141422114/Erwarten-Sie-dass-wir-uns-isolierenlassen.html, 26 May, accessed 14 July 2015.

- Encyclopedia Princetoniensis (2014), http://pesd.princeton.edu/?q=node/255, accessed 14 July 2015.

- Feklyunina, V. and White, S. (2011) 'Discourses of “Krizis”: Economic Crisis in Russia and Regime Legitimacy’, Journal of Communist Studies and Transition Politics, 27, 3-4: 385-406.

- Fish, M.S. (2001) 'When More is Less: Superexecutive Power and Political Underdevelopment in Russia', in Victoria E. Bonnell \& George W. Breslauer (eds), Russia in the New Century: Stability or Disorder? (Boulder: Westview Press).

- Gedmin, J. (2014) ‘Beyond Crimea: What Vladimir Putin Really Wants’, World Affairs, 177, 2: 8-16.

- Gel'man, V. (2010) 'Regime Changes Despite Legitimacy Crises: Exit, Voice, and Loyalty in Post-Communist Russia’ Journal of Eurasian Studies, 1, 1: 54-63.

- Gel'man, V. (2013) 'Cracks in the Wall’ Problems of Post-Communism, 60, 2: 3-10.

- Goscilo, H. (2013) 'Putin’s performance of masculinity: the action hero and macho sex-object', in Helena Goscilo (ed.): Putin as Celebrity and Cultural Icon (London: Routledge), 180-207.

- Greene, S.A. (2013) ‘Beyond Bolotnaia: Bridging Old and New in Russia’s Election Protest Movement', Problems of Post-Communism 60, 2: 40-52.

- Heberer, T. and Schubert, G. (eds) (2008). Regime Legitimacy in Contemporary China: Institutional change and stability (London/New York: Routledge).

- Hedlund, S. (2006) 'Vladimir the Great, Grand Prince of Muscovy: Resurrecting the Russian service state’ Europe-Asia Studies 58, 5: 775-801.

- Holmes, L. (1997) Post-Communism: an Introduction (Durham, NC: Duke University Press).

- Hosking, G. and Schöpflin, G. (eds) (1997) Myths and Nationhood (London, C. Hurst \& Co Publishers).

- Hurd, I. (2008) After Anarchy: Legitimacy and Power in the United Nations Security Council (Princeton University Press).

- Kaczmarski, M. (2014) ‘Domestic Power Relations and Russia’s Foreign Policy’, Demokratizatsiya 22, 3: 383-410. 
- Levada-Centre (2014) 'Otsenka politiki rukovodstva Rossii otnositel’no Ukrainy’, Press Release 30 July 2014. Available online: http://www.levada.ru/30-072014/otsenka-politiki-rukovodstva-rossii-otnositelno-ukrainy, accessed 14 July 2015.

- Levinson, Alexey (2015), 'Who is Mr Putin Now? Current Trends in Russian Opinion', Paper presented at Centre for European Studies, Lund University (Sweden), 16 March. Authors’ own notes from attendance at speech.

- McDonough, P., Barnes, S.H. and López Pina, A. (1986) 'The Growth of Democratic Legitimacy In Spain', The American Political Science Review, 80, 3: 735-760.

- $\quad$ Ministry of Foreign Affairs of the Russian Federation (2013). 'Kontseptisya vneshnei politiki Rossiiskoi Federatsii, http://www.mid.ru/foreign_policy/official_documents//asset_publisher/CptICkB6BZ29/content/id/122186, accessed 14 July 2015.

- Medvedev, D. \& Putin, V. (2012) 'Speech at a rally in support of presidential candidate Vladimir Putin', 4 March, http://eng.kremlin.ru/news/3508, accessed_14 July 2015.

- Morin, R. \& Samaranayake, N. (2006) ‘The Putin Popularity Score’, Pew Research Center Publications, http://pewresearch.org/pubs/103/the-putin-popularity-score, accessed 14 July 2015.

- Neumann, I.B. (2008) 'Russia as a Great Power', Journal of International Relations and Development, 11: 128-151

- Nezavisimaya (2012) 'Sterkh Putna vozvrashchaetsya v Rossiyu', 21 November, http://www.ng.ru/news/421236.html, accessed 14 July 2015.

- ORT News (2000), 'Vladimir Putin v ocherednoi raz prodemonstriroval svoyu sposobnost' povlyat'sya tam, gde ego ne zhdut', 20 March, http://www.1tv.ru/news/2000/03/20/288582-

vladimir_putin_v_ocherednoy_raz_prodemonstriroval_svoyu_sposobnost_poyavlyats ya_tam_gde_ego_ne_zhdut, accessed 1 July 2016.

- Pakulski, J. (1986) 'Bureaucracy and the Soviet system’, Studies in Comparative Communism, 19, 1: 3-24.

- Parland, T. (2005) The Extreme Nationalist Threat in Russia: The Growing Influence of Western Rightist Ideas (New York: Routledge Curzon).

- Persson, E, and Petersson, B. (2014) 'Political mythmaking and the 2014 Winter Olympics in Sochi: Olympism and the Russian great power myth.' East European Politics, 30, 2: 192-209. 
- Peter, F. (2014) 'Political Legitimacy', The Stanford Encyclopedia of Philosophy (Spring 2014 Edition), Edward N. Zalta (ed.), http://plato.stanford.edu/archives/spr2014/entries/legitimacy/, accessed 14 July 2015.

- Petersson, B. (2013) 'The Eternal Great Power Meets the Recurring Times of Troubles: Twin Political Myths in Contemporary Russian Politics’ European Studies: A Journal of European Culture, History and Politics, 30: 301-26.

- Prizel, I. (1998) National Identity and Foreign Policy: Nationalism and Leadership in Poland, Russia and Ukraine (Cambridge: Cambridge University Press).

- Putin, Vladimir. 2000. 'Interview with the RTR TV Channel’, January 23. http://en.kremlin.ru/events/president/transcripts/24126 (accessed 11 August 2016).

- Putin, V. (2005). 'Poslanie Federal'nomu Sobraniyu Rossiiskoi Federatsii', 25 April http://www.kremlin.ru/events/president/transcripts/22931 (Russian); http://en.kremlin.ru/events/president/transcripts/22931 (English), accessed 1 July 2016.

- Putin, V. (2014a) ‘Address by President of the Russian Federation’, 18 March 2014, http://www.kremlin.ru/transcripts/20603 (Russian); http://eng.kremlin.ru/transcripts/6889 (English), accessed 14 July 2015.

- Putin, V. (2014b), 'Direct Line with Vladimir Putin’, 17 April, http://eng.kremlin.ru/news/7034\#sel, accessed 14 July 2015.

- RIA-Novosti (2012) 'Staraya sportivnaya travma Putina ne vlyaet na ego grafik, zayavil Peskov', http://ria.ru/politics/20121101/908486534.html, accessed 14 July 2015.

- Rigby, T.H. (ed.) (1982). Political Legitimation in Communist States (New York: St. Martin's Press).

- Rose, R., Munro, N. and Mishler, W. (2004) 'Resigned Acceptance of an Incomplete Democracy: Russia's Political Equilibrium', Post-Soviet Affairs 20, 3: 195-218.

- Rosstat (Russian State Statistical Agency), Ofitsial'naya statistiki: Natsional'nye scheta [Official Statistics: National Accounts] (database). Available online: http://www.gks.ru/wps/wcm/connect/rosstat_main/rosstat/ru/statistics/accounts/\#, accessed 14 July 2015.

- Rutland, P. (2008) 'Russia as an energy superpower', New Political Economy 13, 2: 203-210. 
- Sakwa, R. (2011) The Crisis of Russian Democracy: The Dual State, Factionalism and the Medvedev Succession (Cambridge: Cambridge University Press).

- Sakwa, R. (2012) 'Russia: from Stalemate to Crisis?', The Brown Journal of World Affairs 19, 1: 231-46.

- Sakwa, R. (2014) Putin Redux: Power and Contradiction in Contemporary Russia (London/New York: Routledge).

- Scharpf, F. (1999) Governing in Europe: Effective and Democratic? (Oxford: Oxford University Press).

- Schlumberger, O. and Bank, A. (2001) 'Succession, Legitimacy, and Regime Stability in Jordan', The Arab Studies Journal 9/10, 2/1: 50-72.

- Sil, R. \& Chen, C. (2004) 'State Legitimacy and the (In) significance of Democracy in Post-Communist Russia’. Europe-Asia Studies, 56, 3: 347-68.

- Sivkova, Alena (2014). 'Est’ Putin - est’ Rossiya. Net Putina - net Rossii', Izvestiya (website version), 22 October 2014: http://izvestia.ru/news/578379, accessed 14 July 2015.

- Smith, A. D. (1991) National Identity (Harmondsworth: Penguin).

- Smyth, R. (2014) 'The Putin Factor: Personalism, Protest, and Regime Stability in Russia’, Politics \& Policy, 42, 4: 567-92.

- Smyth, R., Sobolev, A. and Soboleva, I. (2013), 'A Well-Organized Play: Symbolic Politics and the Effect of the Pro-Putin Rallies', Problems of Post-Communism, 60, 2: 24-39.

- Solovei, V. (2004) 'Rossiya nakanune smuty’ (Russia on the Eve of the Time of Troubles”). Svobodnaya mysl 21, 2: 38-48.

- Teague, E. (2011) 'How Did the Russian Population Respond to the Global Financial Crisis?', Journal of Communist Studies and Transition Politics, 27, 3/4: 420-33.

- Tranter, B. and Donoghue, J. (2014) 'National identity and important Australians' Journal of Sociology 51: 236-51.

- Treisman, D. (2011) 'Presidential popularity in a young democracy: Russia under Yeltsin and Putin', American Journal of Political Science 55, 3: 590-609.

- Weber, M. (2006 - first published 1919), 'Politics as a Vocation', in Dreijmanis, John (ed.), Max Weber's Complete Writings on Academic and Political Vocations. (New York: Algora), 155-207. 
Figure 1: Net approval levels of Putin, 2000-2014 (\% respondents)

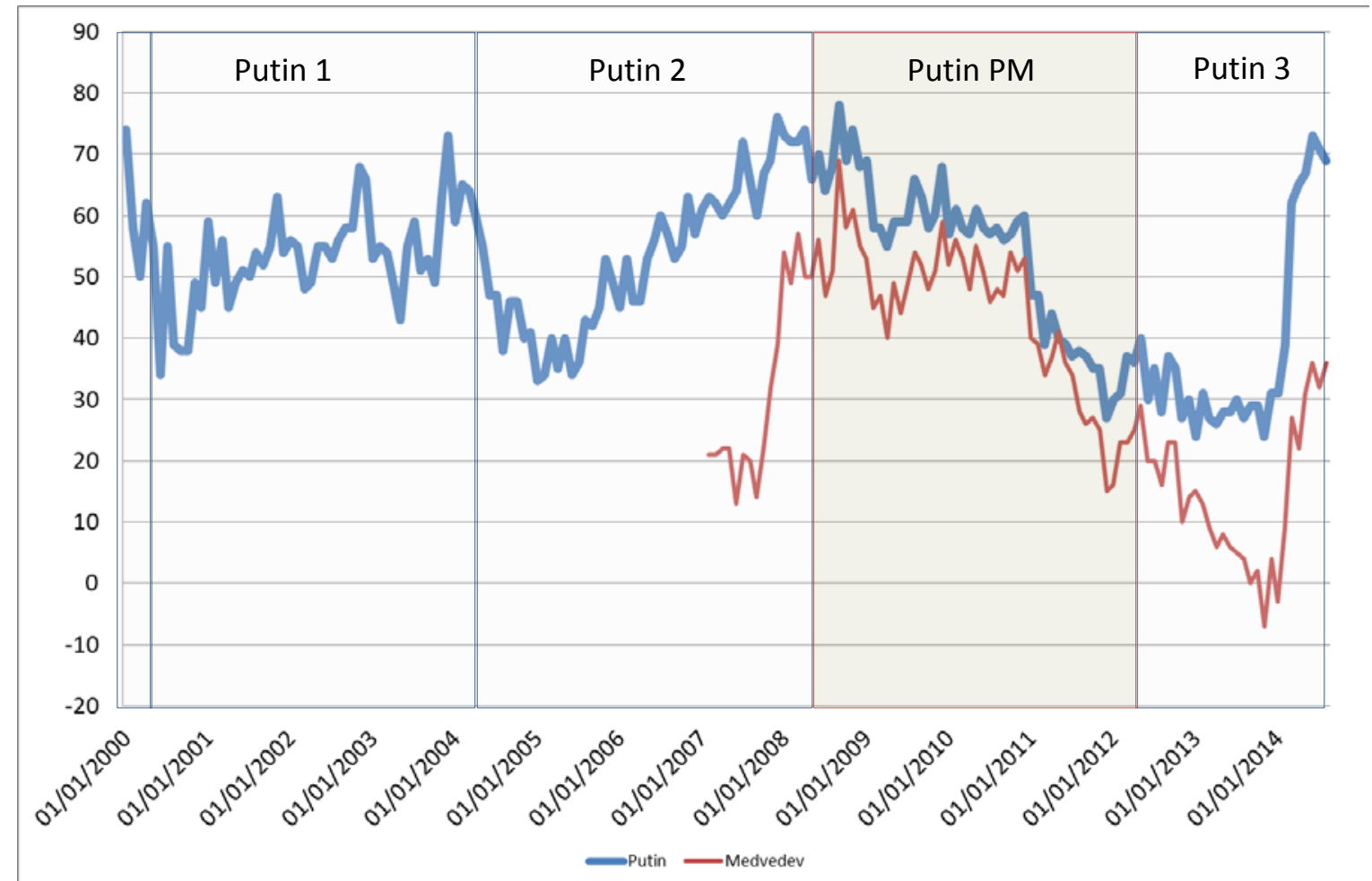

Source: Levada Centre indices (2014): http://www.levada.ru/indeksy, accessed 30 September 2014.

Notes: The lines show the net balance of those who 'approve' of the activities of Vladimir Putin/Dmitrii Medvedev (respectively) from the number who 'disapprove'. 
Table 1: Respondents indicating 'trust' and 'distrust' in state institutions, 2000-12

\begin{tabular}{|l|r|r|r|r|r|r|r|r|r|}
\hline & \multicolumn{4}{|c|}{ Trust } & \multicolumn{4}{|c|}{ Distrust } \\
\hline & $\mathbf{2 0 0 0}$ & $\mathbf{2 0 0 4}$ & $\mathbf{2 0 0 8}$ & $\mathbf{2 0 1 2}$ & $\mathbf{2 0 0 0}$ & $\mathbf{2 0 0 4}$ & $\mathbf{2 0 0 8}$ & $\mathbf{2 0 1 2}$ \\
\hline Church & N/A & 51 & 58 & 56 & N/A & 31 & 24 & 28 \\
\hline Army & 52 & 44 & 49 & 47 & 30 & 33 & 30 & 33 \\
\hline President & 23 & 65 & 68 & 44 & 62 & 18 & 19 & 33 \\
\hline State TV & N/A & 33 & 39 & 37 & N/A & 41 & 39 & 38 \\
\hline Courts & 17 & 20 & 34 & 32 & 64 & 60 & 46 & 49 \\
\hline Government & N/A & 24 & 39 & 32 & N/A & 54 & 39 & 42 \\
\hline Trade Unions & 22 & 21 & 29 & 30 & 61 & 63 & 52 & 49 \\
\hline Private enterprise & 16 & 24 & 25 & 29 & 65 & 54 & 53 & 46 \\
\hline Police & 16 & 14 & 20 & 23 & 66 & 71 & 61 & 55 \\
\hline Regional government & N/A & 18 & 25 & 22 & N/A & 64 & 57 & 54 \\
\hline Parliament & 13 & 10 & 21 & 21 & 70 & 74 & 60 & 59 \\
\hline Parties & 9 & 10 & 16 & 19 & 76 & 75 & 65 & 62 \\
\hline
\end{tabular}

Sources: Calculated from 2000 NRB8 survey, c12; 2004, 2008 and 2012 Russian Research Surveys, B14.

Notes: The questions were 'To what extent do you trust each of the following institutions to look after your interests? (2000) and 'To what extent do you trust each of the following institutions?' (2004-12). Figures in the table are the cumulative percentages of respondents expressing 'trust' and 'distrust' in the institutions listed, expressed as points 1-3 and 5-7 respectively on a 7-point ascending scale. Point ' 4 ' is regarded as neutral, and not shown here. 'Don't Know' and 'No answer' responses have been excluded. Arranged in order of 2012 trust levels. 
Table 2: Correlation between trust and approval ratings, 2004-12 (Pearson correlations) ${ }^{1}$

\begin{tabular}{|l|c|r|r|r|r|r|}
\hline & $\begin{array}{c}\text { Pres. } \\
\text { Trust } \\
\mathbf{2 0 0 4}\end{array}$ & $\begin{array}{c}\text { Govt Trust } \\
\mathbf{2 0 0 4}\end{array}$ & $\begin{array}{c}\text { Pres. Trust } \\
\mathbf{2 0 0 8}\end{array}$ & $\begin{array}{c}\text { Govt Trust } \\
\mathbf{2 0 0 8}\end{array}$ & $\begin{array}{c}\text { Pres. Trust } \\
\mathbf{2 0 1 2}\end{array}$ & $\begin{array}{c}\text { Govt Trust } \\
\mathbf{2 0 1 2}\end{array}$ \\
\hline President Approval & $\mathbf{0 . 5 4 5}$ & 0.318 & $\mathbf{0 . 5 1 8}$ & 0.354 & $\mathbf{0 . 5 0 8}$ & 0.460 \\
\hline PM Approval & $\mathbf{0 . 3 6 2}$ & $\mathbf{0 . 3 9 4}$ & 0.383 & $\mathbf{0 . 3 7 4}$ & 0.499 & $\mathbf{0 . 4 9 0}$ \\
\hline President Trust & 1.000 & 0.453 & 1.000 & 0.641 & 1.000 & 0.737 \\
\hline Government Trust & $\mathbf{0 . 4 5 3}$ & 1.000 & 0.641 & 1.000 & 0.737 & 1.000 \\
\hline
\end{tabular}

Source: Calculated from 2004, 2008 and 2012 Russian Research Surveys, B14 and B22/23 in all cases.

Notes: $\mathrm{N}=2000$ (2004 and 2008); $\mathrm{N}=1600$ (2012). Scores shown are Pearson bivariate correlations, with B22/23 recoded to an ascending, rather than descending scale, to alleviate the effects of scale direction on the correlation score. All are significant at the $p<0.01$ level. Bold boxes indicate the intersections between institutions and incumbents (e.g., trust in the government and approval of the prime minister), and are included for ease of reference only.

\footnotetext{
${ }^{1}$ The presidents were Putin in 2004 and 2008, and Medvedev in 2012. The prime ministers were Mikhail Kas'yanov in 2004, Viktor Zubkov in 2008, and Putin himself in 2012.
} 
Figure 2: Net approval of Vladimir Putin's success in various policy areas (\% respondents)

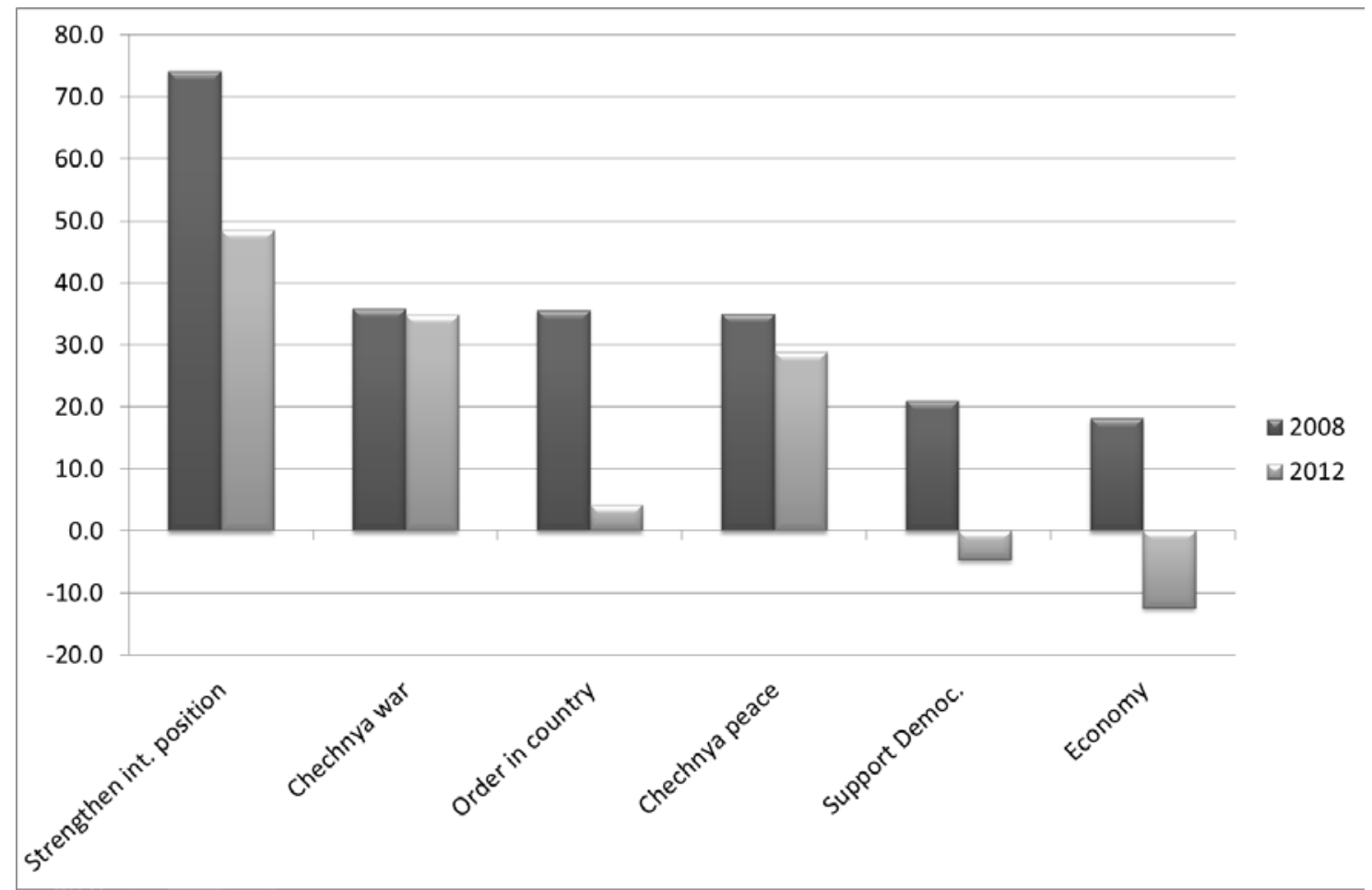

Source: Russian Research surveys 2008 and 2012, question B22 in both cases. 'Don't know' answers excluded. Note: Figure show the combined figures saying that Putin is 'completely unsuccessfully' or 'not very successfully' dealing with a problem subtracted from the combined figure that say he is dealing with it 'very successfully' or 'successfully', as a percentage of respondents. 
Table 3: approval of Vladimir Putin's performance, 2008 and 2012. Multivariate (OLS) regression (standardised Beta co-efficients)

\begin{tabular}{|c|c|c|c|c|c|c|}
\hline & \multicolumn{5}{|c|}{2012} & \multirow{2}{*}{$\begin{array}{r}2008 \\
\text { (Three } \\
\text { pillars) }\end{array}$} \\
\hline & $\begin{array}{c}1 \\
\text { (Base) }\end{array}$ & $\begin{array}{l}2 \\
\text { (Performance) }\end{array}$ & $\begin{array}{l}3 \\
\text { (Threat) }\end{array}$ & $\begin{array}{l}4 \text { (Foreign } \\
\text { policy) }\end{array}$ & $\begin{array}{l}5 \text { (Three } \\
\text { pillars) }\end{array}$ & \\
\hline Adj. $R^{2}$ & 0.012 & 0.278 & 0.286 & 0.224 & 0.409 & 0.457 \\
\hline Age & $-.044^{*}$ & $-.067^{*}$ & 0.042 (ns) & -.030 (ns) & -.047 (ns) & .019 (ns) \\
\hline Sex & $-.082 * *$ & $-.054 *$ & $0.013(\mathrm{~ns})$ & -.050 (ns) & -.010 (ns) & $-.063 * *$ \\
\hline Education & $.070 *$ & $.062 *$ & $.054 *$ & $.068 * *$ & $.075^{* *}$ & .014 (ns) \\
\hline $\begin{array}{l}\text { Putin's success - improving } \\
\text { national prosperity }\end{array}$ & & $.409 * *$ & & & $.201^{* *}$ & $.196 * *$ \\
\hline $\begin{array}{l}\text { Satisfaction with national } \\
\text { affairs }\end{array}$ & & $.132 * *$ & & & $.069 * *$ & $.049 *$ \\
\hline $\begin{array}{l}\text { Russian economy last } 12 \\
\text { months }\end{array}$ & & $.119 * *$ & & & $.057^{*}$ & $.077^{* *}$ \\
\hline $\begin{array}{l}\text { Putin's success - order in } \\
\text { the country }\end{array}$ & & & $.420 * *$ & & $.226^{* *}$ & $.208 * *$ \\
\hline USA unfriendly & & & $\begin{array}{r}-0.030 \\
\text { (ns) } \\
\end{array}$ & & & \\
\hline $\begin{array}{l}\text { Threat from Ukraine in } \\
\text { NATO }\end{array}$ & & & $\begin{array}{r}0.031 \\
\text { (ns) }\end{array}$ & & & \\
\hline $\begin{array}{l}\text { Putin's success - defeat } \\
\text { Chechen rebels }\end{array}$ & & & $.215^{* *}$ & & $.083^{* *}$ & $.081 * *$ \\
\hline $\begin{array}{l}\text { Putin's success - Consolidate } \\
\text { international position }\end{array}$ & & & & $.296 * *$ & $.125^{* *}$ & $.105^{* *}$ \\
\hline $\begin{array}{l}\text { Approve of Russia's foreign } \\
\text { policy }\end{array}$ & & & & $.313^{* *}$ & $.200 * *$ & $.213^{* *}$ \\
\hline
\end{tabular}

Source: Russian Research Survey 2012.

Notes: ${ }^{*}=$ significant at $p<0.05$ level; ${ }^{* *}=$ significant at the $p<0.01$ level; $(n s)=$ not significant 